\title{
Estimating Solar Radiation Intensity from Other Meteorological Data
}

\author{
Modesto Capiel \\ INTRODUCTION
}

Solar radiation is the sole source of energy for plant life. Like water, it is indispensable for plant growth and, with water, establishes the main. aspects of the ecosystem of plant communities. Solar radiation provides: the energy for photosynthesis, although most of the energy flux is partitioned between latent heat of vaporization and sensible or environmentali heat.

As received at the earth's surface, solar energy includes mostly visible. light with wavelengths between 400 and $760 \mathrm{~m} \mu$, and infrared or thermal radiation with wavelengths above $760 \mathrm{~m} \mu$. A good part of this latter portion. is attenuated along its path from the upper layer of the atmosphere to. the earth's surface. This is due mainly to absorption by water vapor. The visible light, around 44 percent of the total radiation, is received largely unaffected at the earth's surface. A relatively small portion is ultraviolet with wavelengths shorter than the visible light. Much of the solar ultraviolet is absorbed by the ozone layer of the upper atmosphere, $25 \mathrm{~km}$. up. This is fortunate for plant life because of the detrimental effect of this component.

Three things need to be known about solar radiation: 1, Intensity, 2, wave-length composition and 3, photoperiod or duration. Intensity, the subject of this paper, is usually expressed in terms of energy units such as ergs per square $\mathrm{cm}$., langleys, British thermal units or $\mathrm{mm}$. of equivalent evaporation. The photofield measurements of radiation intensity include direct sunshine, sky radiation, and the back radiation from the earth. These are the three main components of the total radiation. Instruments measuring the total solar and sky radiation falling upon a horizontal surface include among others the Eppley pyrheliometer, the Beckman and Whitley hemispherical thermal radiometer, the Kipp solarimeter and others. In all these instruments, the flux density of solar energy received on a horizontal surface depends on the solar altitude or angle, the turbidity of the atmosphere and cloud conditions.

1 Associato Soil Scientist, Agricultural Experiment Station, Mayagüez Campus, University of Puerto Rico, Río Piedras, P.R. Appreciation is expressed to Dr. Bernardo G. Cap6, Technical Consultant to the Director and to Mr. M. Antoni, Research Assistant, for their valuable criticism in the statistical consideration of the data and their cooperation in running the statistical analysis, respectively. 
As an environmental factor, solar radiation interacts with the other atmospheric components as well as with organisms, including plants, to produce certain physical and biological changes. An evaluation of these intèractions is very important in such studies as the energy budget of an environment, phenological relationships, and in the relation of crop yields to climatic data. According to Saecki $(6)^{2}$ the importance of the light factor in plant communities was first elucidated by Jansen in 1932, in relation to dry matter production. However, only recently has great interest in light relations to crop production been developed.

The usefulness of data on plant response to light intensity relies on the precision of the physical and the biological measurements. Brouwer (2) correlated the rate of transpiration with the radiation intensity in the Netherlands. Kramer and Decker (5) found the rate of photosynthesis in loblolly pine and other trees to be closely related to light intensity. Capiel (B) observed that solar energy, included alone or in multiple regression analysis, exhibited high correlation when compared to the yield, by harvests, of irrigated forage.

Solar radiation intensity is not commonly measured as a meteorological factor in most weather stations. Reliable solar radiation recording instruments are more expensive than temperature and humidity recorders. Less expensive instruments give instantaneous measures of light intensity, of limited application in research. On the other hand, accumulated values of solar energy are not as easily obtained as those of wind speed and of open pan evaporation. Yet, as mentioned earlier, this kind of data is becoming highly and increasingly valuable in biological research.

The evaporation rate from a water surface is a function of the available energy at the air-water interface. Since solar energy is by far the most important energy source operating in open pan evaporation as latent heat of vaporization, it should be possible to estimate the intensity of solar energy from pan evaporation if provision is made to account for other significant contributing factors. In addition to the latent heat of vaporization, the sensible heat flux is an important component of the energy balance. Thus, it should be given at least indirect consideration in solving for the incident solar energy. The water-heat flux and the pan-walls-heat flux are indirectly accounted for in the quantitative measurement of evaporation as long as a complete day, or days, are considered. Both storage components, operating at night in the opposite direction, are proportional to the daytime incident solar energy, as long as advected heat does not constitute another important source of evaporation.

Baier and Robertson (1) attempted to evaluate the influence of several

Italic numbers in parentheses refer to Literature Cited, p. 389. 
meteorological parameters on latent evaporation, as measured from a black porous surface. Maximum and minimum temperatures and extraterrestrial radiation obtained from tables, correlated significantly with latent evaporation. The addition of any one or more of the variables solar energy, vapor pressure deficit, or wind resulted in increases of correlation coefficient ranging from 0.75 to 0.81 . With all six variables involved the coefficient increased to 0.84 . This means that 70 percent of the variations in latent evaporation were explained by variations of the mentioned meteorological factors.

\section{MATERIALS AND METHODS}

Various meteorological components were measured in a field of the Agricultural Experiment Station located at Gurabo from August 1965 to July 1966 in conjunction with an irrigated forage experiment. The weather data obtained included solar radiation, air temperature, relative humidity, wind movement and open pan evaporation.

Total incoming solar radiation was measured with an Eppley pyrheliometer, 50 junction model, and was recorded on a Leeds and Northrup, Speedomax H recorder. A disk chart integrator was connected to the recorder, together with a rotaswitch counter. This provided an integration of the solar radiation in addition to the strip chart record. A calibration curve was prepared accordingly to interpret the data in $\mathrm{mm}$. of evaporation per day and in langleys per day. Solar radiation was also measured with a Gun-Bellani radiation integrator. ${ }^{3}$

The air temperature and the relative humidity were continuously recorded with a Schreibstreifen Hygrothermograph housed in a standard cotton region shelter, located centrally in the experimental site. The temperature and humidity readings were checked at least weekly with a psychrometer. Areas on the recorder charts were determined with a planimeter. The mean values of temperature and humidity were calculated from the integrated values. A special curve was constructed for the mean daily relative humidity calculations, as the area of the charts changes inversely and exponentially with a given humidity increment. The moisture condition of the atmosphere was then converted to saturation vapor pressure deficit by means of the equation:

$$
e_{d}=e_{a}-e_{s}(\mathrm{RH})
$$

where $e_{d}$ is saturation deficit, $e_{s}$ is the saturated vapor pressure correspond-

8 Manufactured by Baird and Tatlock (London) Ltd. Mention of trade names in this report does not imply endorsement of particular equipment by the Agricultural Experiment Station, University of Puerto Rico. Such names are mentioned for the sole purpose of identifying the type of equipment used in this research. 
ing to the mean daily temperature, and $R H$ is the mean daily relative humidity.

Pan evaporation was measured with a plastic U. S. Weather Bureau type pan. Pan readings were adjusted for any precipitation using measurements taken from a rain gauge located at the side of the evaporation pan. The wind speed was obtained from an anemometer located next to the evaporation pan. The anemometer height was $45 \mathrm{~cm}$.

Fifteen-day mean values of solar energy $\left(R_{i}\right)$, air temperature $\left(T_{a}\right)$, wind speed $(u)$, and saturation vapor pressure deficit $\left(e_{d}\right)$ were used in evaluating their individual influences on evaporation $\left(E_{0}\right)$ from an open pan. Simple regression analysis was used. Multiple regression was also used to evaluate further the multiple weather influence on evaporation and determine which combination of factors could best be used for prediction. The independently measured weather factors $\left(R_{i}, T_{a}, u\right.$, and $\left.e_{d}\right)$ were placed into a multiple regression equation in decreasing order of influence on evaporation, as determined by simple regression. The model multiple regression equation employed was:

$$
E_{o}=a_{o}+b_{1} x_{1}+b_{2} x_{2}+b_{2} x_{3}+b_{4} x_{4} \cdots / 1 /
$$

where $x_{1}$ through $x_{4}$ represent the weather elements $\left(R_{i}, T_{a}, u\right.$, and $\left.e_{d}\right)$ in decreasing order of influence as determined by simple regression, $b_{1}$ through $b_{4}$ represent the partial regression coefficients associated with $x_{1}$ through $x_{4}$, and $a_{0}$ represents a parameter to be estimated. Weather elements finally were ordered by placing first in the equation those terms that made the most significant contribution in multiple regression, as evaluated by resulting " $F$ " values. Any term that did not appear to increase the contribution to multiple regression was dropped from the equation.

Estimates of solar radiation were first calculated by proper arithmetic substitution in the most significant equation resulting from equation /1/. Ratios of estimated to measured values of $R_{i}$ were then calculated as well as their standard deviations and coefficients of variation.

The 15-day periods were further divided into shorter periods of from 1 to 5 days and subjected to a similar analysis of their weather data.

Subsequent to obtaining a regression of pan evaporation on $R_{i}, u, T_{a}$, and $e_{d}$, eliminating any meteorological parameter that would not contribute significantly to predict $E_{o}$, and to solving for $R_{i}$ by arithmetic substitution from the obtained equation, a direct regression of $R_{i}$ on the other significantly related weather factors was performed. Although solar radiation is entirely independent of all other meteorological factors, this procedure is mathematically correct as it minimizes the deviations about regression in terms of the solution for $R_{i}$. This approach was considered justified, subject to obtaining a previous highly significant multiple regres- 
sion of $E_{o}$ on $R_{i}$ and other meteorological weather components contributing to evaporation.

As a final step, the indirect and the direct solutions of $R_{i}$ by multiple regression were compared by evaluating both equations on foreign data representing extreme meteorological conditions such as those prevailing in areas of Israel and Panamá $(4,7)$.

TABLE 1.-Mean values of weather elements calculated for around 16-day periods along one year

\begin{tabular}{|c|c|c|c|c|c|}
\hline $\begin{array}{l}\text { Date } \\
\text { to: }\end{array}$ & $\begin{array}{c}\text { Pan } \\
\text { evaporation }\end{array}$ & $\begin{array}{c}\text { Solar } \\
\text { energy }\end{array}$ & $\underset{\text { temperature }}{\text { Air }}$ & $\begin{array}{l}\text { Wind } \\
\text { speed }\end{array}$ & $\begin{array}{c}\text { Saturation } \\
\text { deficit }\end{array}$ \\
\hline $\begin{array}{c}6-25 \\
7-10 \\
7-25 \\
8-9 \\
8-25 \\
9-8 \\
9-24 \\
10-11 \\
10-23 \\
11-8 \\
11-23 \\
12-7 \\
12-23 \\
1-7 \\
1-21 \\
2-5 \\
2-21 \\
3-7 \\
3-23 \\
4-6 \\
4-21 \\
5-6 \\
5-23 \\
6-5\end{array}$ & $\begin{array}{c}\text { Mm. per doy } \\
4.76 \\
4.06 \\
5.25 \\
4.76 \\
4.17 \\
5.64 \\
4.11 \\
4.45 \\
3.30 \\
3.32 \\
3.16 \\
2.79 \\
2.40 \\
2.65 \\
3.32 \\
3.50 \\
3.73 \\
4.65 \\
4.18 \\
5.20 \\
4.70 \\
5.22 \\
4.90 \\
5.44\end{array}$ & $\begin{array}{c}\text { Mm. per day } \\
\mathbf{8 . 6 1} \\
\mathbf{7 . 8 2} \\
\mathbf{8 . 7 0} \\
\mathbf{7 . 8 9} \\
\mathbf{6 . 8 2} \\
\mathbf{9 . 5 8} \\
6.84 \\
\mathbf{8 . 2 5} \\
\mathbf{7 . 0 8} \\
\mathbf{7 . 3 5} \\
6.99 \\
6.37 \\
6.13 \\
\mathbf{6 . 1 8} \\
\mathbf{7 . 2 5} \\
\mathbf{7 . 5 4} \\
\mathbf{6 . 8 5} \\
\mathbf{8 . 6 1} \\
\mathbf{7 . 9 0} \\
\mathbf{8 . 7 5} \\
\mathbf{8 . 4 2} \\
\mathbf{8 . 4 7} \\
\mathbf{8 . 4 4} \\
\mathbf{7 . 9 0}\end{array}$ & $\begin{array}{c}{ }^{\circ} \mathrm{C} \\
25.7 \\
24.9 \\
25.2 \\
25.5 \\
25.7 \\
27.4 \\
25.3 \\
25.5 \\
23.1 \\
24.6 \\
23.4 \\
21.3 \\
24.5 \\
23.0 \\
23.0 \\
23.0 \\
21.6 \\
23.4 \\
23.1 \\
24.5 \\
24.5 \\
23.2 \\
25.0 \\
24.0\end{array}$ & $\begin{array}{c}\text { Km. per day } \\
\mathbf{5 7 . 3} \\
\mathbf{5 4 . 9} \\
\mathbf{5 4 . 7} \\
47.8 \\
48.0 \\
67.9 \\
39.1 \\
45.1 \\
30.4 \\
37.5 \\
32.0 \\
38.5 \\
23.7 \\
43.0 \\
39.9 \\
36.7 \\
\mathbf{7 6 . 6} \\
63.4 \\
62.1 \\
56.8 \\
51.7 \\
\mathbf{9 9 . 5} \\
64.2 \\
90.8\end{array}$ & $\begin{array}{c}m b \\
6.70 \\
5.51 \\
4.74 \\
3.62 \\
4.89 \\
5.91 \\
3.13 \\
5.45 \\
3.00 \\
4.30 \\
3.45 \\
4.10 \\
6.09 \\
5.48 \\
4.61 \\
5.22 \\
4.10 \\
4.26 \\
4.69 \\
7.53 \\
5.78 \\
6.71 \\
4.88 \\
5.60\end{array}$ \\
\hline Mean & 4.15 & 7.70 & 24.2 & 52.6 & 4.99 \\
\hline
\end{tabular}

\section{RESULTS AND DISCUSSION}

The mean values of $E_{o}, R_{i}, u, T_{a}$, and $e_{d}$, calculated for 15-day periods during 1965-66 in Gurabo are given in table 1 . The statistical results obtained by simple linear regression when relating open pan evaporation to each of the individual weather elements $\left(R_{i}, T_{a}, u\right.$, and $\left.e_{d}\right)$ are given on table 2. It is apparent that solar energy is the single weather element that can best be used to predict pan evaporation. Under the environmental 
TABLE 2.-Siatistical data related to the linear regression of open pan evaporation as a function of different weather elements

\begin{tabular}{l|c|c|c|c}
\hline \multirow{2}{*}{ Weather factor } & $\begin{array}{c}\text { Regression } \\
\text { coeffient }\end{array}$ & \multicolumn{2}{|c|}{ Coeffients of- } & \multirow{2}{*}{ "F" values } \\
\cline { 3 - 4 } & & Correlation & $\begin{array}{c}\text { Determina- } \\
\text { tion }\end{array}$ & \\
\hline & $b$ & $r$ & $r^{*}$ & \\
Solar energy & 0.903 & 0.887 & 0.786 & $80.94^{* *}$ \\
Wind speed & 0.059 & .724 & .525 & $24.28^{* *}$ \\
Air temperature & 0.383 & .583 & .340 & $11.31^{* *}$ \\
Saturation deficit & 0.313 & .386 & .149 & 3.86 \\
\hline
\end{tabular}

** Significant at the 1-percent level.

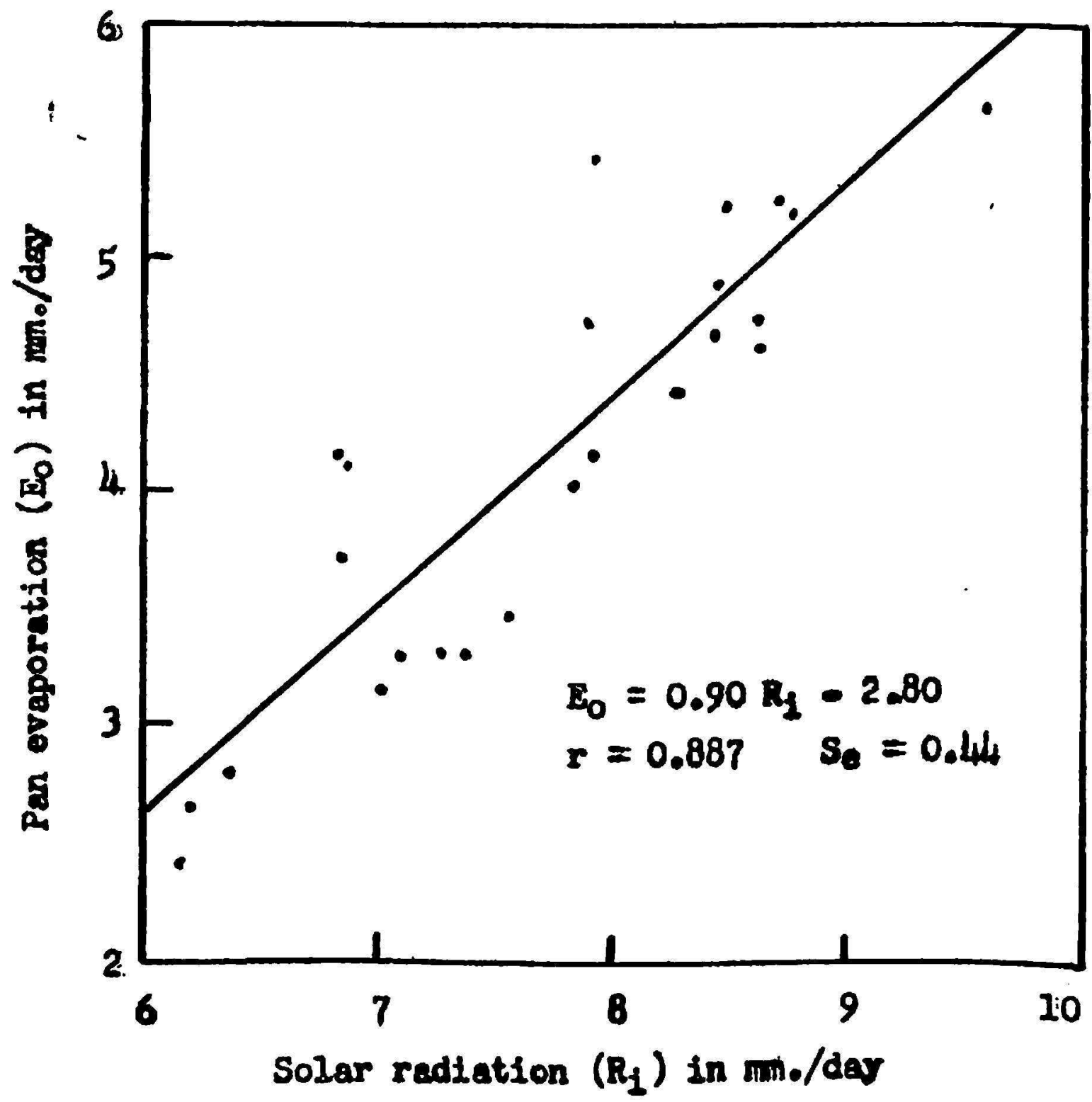
Rico.

Fra. 1. Linear regression of pan evaporation on solar radiation at Gurabo, Puerto 
conditions that prevailed, solar energy accounted for 78.6 percent of the variations in pan evaporation. The data for this relationship is plotted on figure 1 along with the linear regression curve. Next to solar energy, wind speed and air temperature, in this order, appeared to correlate significantly with pan evaporation. They accounted for 52.5 and 34.0 percent of the variations in pan evaporation, respectively. The saturation vapor pressure deficit was not significantly related to open pan evaporation.

Multiple regression analysis was next used to evaluate the combined weather influence on pan evaporation. Terms were included in the multiple regression equation beyond $R_{i}$ in the order $u, T_{a}$, and $e_{d}$ on the basis of the simple linear regression correlation (table 2). Table 3 gives a relation of the coefficients of correlation and determination obtained as the weather

TABLE 3.-Statistical data related to the multiple regression analysis of pan evaporation as a function of different combinations of weather elements

\begin{tabular}{l|c|c|c}
\hline \multirow{2}{*}{ Weather factor inc'uded } & \multicolumn{2}{|c|}{ Coefficients of } & \multirow{2}{*}{ " $F "$ values } \\
\cline { 2 - 3 } & Correlation & Determination & \\
\cline { 2 - 3 }$R_{i}$ & $R$ & $R^{z}$ & \\
$R_{i}, u$ & 0.887 & 0.786 & $80.94^{* *}$ \\
$R_{i}, u, T_{a}$ & .931 & .867 & $68.26^{* *}$ \\
$R_{i}, u, T_{a}, e_{d}$ & .959 & .920 & $76.96^{* *}$ \\
$R_{i}, u, e_{d}$ & .964 & .930 & $63.38^{* *}$ \\
$R_{i}, T_{a}$ & .933 & .871 & $45.09^{* *}$ \\
$R_{i}, e_{d}$ & .896 & .804 & $42.98^{* *}$ \\
$T_{a}, u$ & .887 & .786 & $38.64^{* *}$ \\
& .899 & .808 & $44.10^{* *}$ \\
\hline
\end{tabular}

** Significant at the 1-percent level.

factors were added in the order mentioned above, and also by substituting some terms. Wind speed appears to be the most influential weather factor beyond solar energy. Together, both account for 86.7 percent of the variations in pan evaporation. The corresponding multiple regression equation is

$$
E_{o}=0.713 R_{i}+0.045 u-2.243 \cdots / 2 /
$$

where $E_{o}$ and $R_{i}$ are expressed in mm. of water per day, and $u$ is expressed in $\mathrm{km}$. per day.

Table 3 also shows that the addition or the substitution of the term saturation deficit does not contribute appreciably to predict pan evaporation under the prevailing environmental conditions, and as long as wind speed and air temperature have been previously included in the equation. Incorporating the latter term, $T_{a}$, to equation /2/ so that

$$
E_{o}=0.507 R_{i}+0.056 u+0.189 T_{a}-5.477 \cdots / 3 /
$$


where $T_{a}$ is expressed in ${ }^{\circ} \mathrm{C}$, increases the significance of multiple regression in predicting $E_{o}$. Equation /3/ accounts for 92.0 percent of the variations in open pan evaporation that can be attributed to $R_{i}, u$, and $T_{a}$. The multiple correlation coefficient is 0.959 . The three partial regression coefficients associated with $R_{i}, u$, and $T_{c}$ are significant at the one percent level, as indicated by their corresponding $t$ values.

By solving for $R_{i}$ from equation $/ 3 /$, so that

$$
R_{i}=\left(E_{o}-0.056 u-0.189 T_{a}+5.477\right)(1.972) \cdots / 4 /
$$

estimated values of solar energy representing 15-day periods were calculated. Ratios of the estimated $R_{i}$ by equation $/ 4 /$ to the correspondingly measured values (table 1) are shown on table 4 . The estimated values approach closely the measured values as may be deducted from the low standard deviation (0.051) and coefficient of variation of 5.1 percent.

The value of equation / 4 / to estimate $R_{i}$ for shorter periods ( 1 to 5 days) was tested next. Values of solar energy for these periods, measured and estimated from equation /4/ are also shown in table 4 . The corresponding ratios of $R_{i}$ (estimated) $/ R_{i}$ (measured) also appear on this table. Their mean value (0.95), their standard deviation (0.085) and their coefficient of variation (8.9 percent) are reasonably close to the corresponding values of the original 15-day data, suggesting that equation /4/ may be used advantageously to estimate $R_{i}$ in the experimental area for shorter periods.

Solving for $R_{i}$ from equation $/ 2 /$ we obtain

$$
R_{i}=\left(E_{o}-0.045 u+2.243\right)(1.403) \cdots / 5 /
$$

which excludes air temperature $\left(T_{\circ}\right)$ as one of the parameters. Estimates of $R_{i}$ obtained by this equation for the short periods of from 1 to 5 days also appear in table 4, together with their corresponding estimated to measured $R_{i}$ ratios. The neglect of $T_{a}$ on equation $/ 5 /$ appears to make this equation less valuable than equation /4/ to estimate solar radiation, as may be concluded from the over four-fold increase in the standard deviation and coefficient of variation of the estimated to measured $R_{i}$ ratios.

It is difficult to escape the conclusion that $E_{o}, T_{a}$, and $u$, altogether, combine in the proportion established by their partial regression coefficients to convey substantial quantitative equivalence of the latent, sensible and momentum fluxes derived from the solar energy breakdown and its impact on aerodynamics. Accordingly, a direct regression of $R_{i}$ on this meteorological indices was carried out, minimizing thus the deviations about the regression of $R_{i}$ directly. The equation

$$
R_{i}=1.155 E_{o}-0.015 u-0.086 T_{a}+5.755 \cdots / 6 /
$$


accounts for 81.2 percent of the variations in $R_{i}$ that may be attributed to $E_{o}, u$ and $T_{a}$. This is nearly 11 percent less than what $R_{i}, u$ and $T_{a}$ explain of the variations of $E_{0}$ by equation $/ 3 /$. The multiple correlation coefficient

TABLE 4.-Estimated and measured solar energy $\left(R_{i}\right)$ in $\mathrm{mm}$. per day, for various periods of time, and the ratios of estimated to measured $R_{i}$

\begin{tabular}{|c|c|c|c|c|c|c|c|}
\hline \multirow{2}{*}{$\begin{array}{l}\text { Estimated } R_{i} \\
\text { by equation } \\
\vdots\end{array}$} & \multirow{2}{*}{$\underset{\boldsymbol{R}_{i}}{\text { Meaured }}$} & \multirow{2}{*}{$\begin{array}{c}\text { Ratio of: } \\
\text { estimated } R_{i} \\
\text { to measured } R_{i}\end{array}$} & \multicolumn{2}{|c|}{$\begin{array}{c}\text { Estimated } R_{i} \text { by } \\
\text { equations }\end{array}$} & \multirow[t]{2}{*}{$\underset{R_{i}}{\text { Measured }}$} & \multicolumn{2}{|c|}{$\begin{array}{l}\text { Ratio of: estimated } \\
R_{f} \text { to measured } R_{i} \text { mestimated } \\
\text { with } R_{i} \text { estimations } \\
\text { fromustions equate }\end{array}$} \\
\hline & & & $|4|$ & $/ 5 /$ & & $|4|$ & $|5|$ \\
\hline \multicolumn{3}{|c|}{ 15-day periods } & \multicolumn{5}{|c|}{ 1- to 5-day periods } \\
\hline $\begin{array}{l}8.15 \\
7.18 \\
9.43 \\
8.64 \\
7.40 \\
8.80 \\
7.81 \\
8.14 \\
7.40 \\
6.57 \\
6.94 \\
6.70 \\
5.40 \\
5.62 \\
7.06 \\
7.55 \\
6.82 \\
8.54 \\
7.77 \\
9.49 \\
8.74 \\
8.20 \\
8.40 \\
8.36\end{array}$ & $\begin{array}{l}8.61 \\
7.82 \\
8.70 \\
7.89 \\
6.82 \\
9.58 \\
6.84 \\
8.25 \\
7.08 \\
7.35 \\
6.99 \\
6.37 \\
6.13 \\
6.18 \\
7.25 \\
7.54 \\
6.85 \\
8.61 \\
7.90 \\
8.75 \\
8.42 \\
8.47 \\
8.44 \\
7.90\end{array}$ & $\begin{array}{l}0.95 \\
0.92 \\
1.08 \\
1.09 \\
1.08 \\
0.92 \\
1.14 \\
0.99 \\
1.05 \\
0.89 \\
0.99 \\
1.05 \\
0.88 \\
0.91 \\
0.97 \\
1.00 \\
1.00 \\
0.99 \\
0.98 \\
1.08 \\
1.04 \\
0.97 \\
1.00 \\
1.06\end{array}$ & $\begin{array}{r}10.18 \\
9.43 \\
8.76 \\
7.48 \\
8.78 \\
7.59 \\
6.94 \\
5.72 \\
8.40 \\
8.52 \\
9.94 \\
7.79 \\
10.14 \\
6.98 \\
7.93 \\
13.74 \\
11.30 \\
7.75 \\
7.04 \\
7.89 \\
10.27 \\
8.52 \\
4.67 \\
5.19\end{array}$ & $\begin{array}{r}10.14 \\
9.59 \\
8.93 \\
7.31 \\
8.34 \\
7.48 \\
6.75 \\
5.91 \\
7.56 \\
7.62 \\
9.20 \\
7.42 \\
8.93 \\
6.94 \\
7.64 \\
12.22 \\
10.57 \\
7.62 \\
7.04 \\
8.16 \\
9.60 \\
8.64 \\
5.53 \\
5.67\end{array}$ & $\begin{array}{r}10.94 \\
10.13 \\
9.61 \\
8.09 \\
9.56 \\
8.78 \\
7.92 \\
6.80 \\
8.65 \\
9.54 \\
10.80 \\
8.90 \\
9.68 \\
8.06 \\
8.63 \\
12.62 \\
11.06 \\
7.96 \\
8.49 \\
8.78 \\
9.59 \\
8.21 \\
4.58 \\
4.48\end{array}$ & $\begin{array}{r}0.93 \\
.93 \\
.91 \\
.92 \\
.92 \\
.86 \\
.88 \\
.84 \\
.97 \\
.89 \\
.92 \\
.87 \\
1.04 \\
.87 \\
.92 \\
1.09 \\
.98 \\
.97 \\
.83 \\
.90 \\
1.07 \\
1.04 \\
1.02 \\
1.16\end{array}$ & $\begin{array}{r}0.93 \\
.95 \\
.93 \\
.90 \\
.87 \\
.85 \\
.85 \\
.87 \\
.87 \\
.80 \\
.85 \\
.83 \\
.92 \\
.86 \\
.88 \\
.97 \\
.96 \\
.96 \\
.83 \\
.93 \\
1.00 \\
1.05 \\
1.21 \\
1.27\end{array}$ \\
\hline \multicolumn{2}{|c|}{$\begin{array}{l}\text { Mean of ratio } \\
\text { Standard deviation } \\
\text { Coefficient of varia- } \\
\text { tion (percent) }\end{array}$} & $\begin{array}{l}1.00 \\
0.051 \\
5.1\end{array}$ & & & & $\begin{array}{l}0.95 \\
0.085 \\
8.9\end{array}$ & $\begin{array}{l}0.93 \\
0.358 \\
38.5\end{array}$ \\
\hline
\end{tabular}

of equation $/ 6 /$ is 0.901 . Only the partial regression coefficient associated with $E_{0}$ was significant at the 1-percent level.

With equation /6/ available to furnish closest estimates of solar radiation of the original 15-day periods data, equation /4/ (the indirect solution) 
was compared to it on the basis of the closeness both approached mean monthly measured values of $R_{i}$ for Bet Dagan in Israel (4), Cristobal in Panamá ( $(7)$, and Río Piedras in Puerto Rico.

TABLE 5.-Slatistical data obtained by linear regression analysis when comparing the estimated solar radiation by equations /4/ and /6/ with the measured solar radiation of three regions. The analyzed dala represent mean monthly values

\begin{tabular}{|c|c|c|c|c|c|c|}
\hline \multirow{3}{*}{ Data compared } & \multicolumn{6}{|c|}{ Regions } \\
\hline & \multicolumn{2}{|c|}{ Bet-Dagan, Israel } & \multicolumn{2}{|c|}{ Cristobal, Panamá } & \multicolumn{2}{|c|}{ Rfo Piedras, Puerto Rico } \\
\hline & Equation /4/ & Equation /6/ & Equation /4/ & Equation /6/ & Equation /4/ & Equation /6/ \\
\hline $\begin{array}{l}\text { Period cov- } \\
\text { ered } \\
\text { Mean meas- } \\
\text { ured } R_{i} \text { in } \\
\text { mm./day }\end{array}$ & $\begin{array}{c}43 \text { months } \\
(1961-64) \\
8.36\end{array}$ & $\begin{array}{c}43 \text { months } \\
(1961-64) \\
8.36\end{array}$ & $\begin{array}{c}60 \text { months } \\
(1960-65) \\
7.22\end{array}$ & $\begin{array}{c}60 \text { months } \\
(1960-65) \\
7.22\end{array}$ & \begin{tabular}{|}
22 months \\
$(1964-65)$ \\
8.25
\end{tabular} & $\begin{array}{c}22 \text { months } \\
(1964-65) \\
8.25\end{array}$ \\
\hline $\begin{array}{l}\text { Mean esti- } \\
\text { mated } R_{i} \\
\text { in mm./ } \\
\text { day }\end{array}$ & 10.08 & 9.77 & 6.78 & 7.34 & 8.06 & 8.86 \\
\hline $\begin{array}{c}\text { Regression } \\
\text { coefficient } \\
\text { (slope) }\end{array}$ & 1.738 & 1.216 & 0.977 & 0.647 & 0.884 & 0.761 \\
\hline $\begin{array}{l}\text { Intercept } \\
\text { (a) }\end{array}$ & -4.442 & -0.396 & -0.275 & 2.668 & 0.765 & 2.576 \\
\hline "F" values & 478.0 & 379.6 & 183.0 & 208.9 & 18.8 & 33.4 \\
\hline $\begin{array}{l}\text { Correlation } \\
\text { coeffi- } \\
\text { cient }^{1}(r)\end{array}$ & 0.960 & 0.950 & 0.872 & 0.885 & 0.696 & 0.791 \\
\hline $\begin{array}{l}\text { Standard } \\
\text { error of } \\
\text { estimate } \\
\left(S_{\odot}\right)\end{array}$ & 1.205 & 0.946 & 0.740 & 0.458 & 1.071 & 0.691 \\
\hline $\begin{array}{l}\text { Standard } \\
\text { error of } \\
\text { the re- } \\
\text { gression } \\
\text { coeff- } \\
\text { cient }\left(S_{b}\right)\end{array}$ & 0.079 & 0.062 & 0.072 & 0.045 & 0.204 & 0.132 \\
\hline
\end{tabular}

${ }^{1}$ All the correlations are significant at the 1-percent level.

Table 5 summarizes the statistical results obtained by linear regression analysis when comparing the estimated solar radiation by equations /4/ and /6/ with the correspondingly measured solar radiation of the three regions mentioned above. 
At first sight it appears from the correlation coefficients in table 5 that both equations, /4/ and /6/, yield estimates of $R_{i}$ highly correlated to the actual mean monthly $R_{i}$, and that abroad (under extreme meteorological conditions), the correlations are even higher than those for Río Piedras; only $25 \mathrm{~km}$. from Gurabo. This is encouraging, as open pan evaporation proceeds similarly everwhere, largely in response to the atmospheric evaporative demands defined by the solar energy intensity and the atmospheric turbulence which governs the eddy diffusion of heat and water vapor. Moreover, the agreement between equations /4/ and /6/ for any of the regions is such that both equations account for nearly the same high percent of the variations in estimated $R_{i}$ that can be attributed to the measured values. The relative similarity between the corresponding " $F$ " values on each region, which represent the ratios of the mean square of the variations due to regression to the mean square of the deviations about regression, support this view.

It is likely that advected energy is an important factor contributing to the evaporation rate (oasis effect) from an open pan in Bet Dagan during the time of year when evaporative demands are greatest. Pan evaporation during this time frequently exceeded or equalled solar radiation there. Therefore, the overestimation of solar energy by equation /4/ may be explained as follows: Equation /3/, from which equation /4/ is obtained, may also be written as

$$
E_{o}=0.507 R_{i}+0.056 u+0.189 T_{a}-5.477+\epsilon \cdots / 7 /
$$

and we can refer to $\epsilon$ (error) the small amount of advected heat which probably contributed to evaporation rate along the experimental year in Gurabo. Because the standard error of estimate $\left(S_{B}\right)$ of equation $/ 3 /$ was found to be only $0.283 \mathrm{~mm}$./day, only about this much can be referred to $\epsilon$ on equation $/ 7 /$. If advection is far greater in Bet Dagan than in Gurabo, as is likely, $\epsilon$ is underestimated in equation / $7 /$ when applied to Bet Dagan. Therefore on deriving equation $/ 4$ / from $/ 3 /$, but as it appears on equation $/ 7 /$, overestimates of solar radiation are unavoidable as a result of the low provision that $\epsilon$ (originated in Gurabo) makes for advected heat on equation $/ 7 /$. In Gurabo, where equation /7/ was evaluated, $R_{i} \gg E_{o}$ always, while in Bet Dagan $R_{i}>E_{o}$.

It is concluded from the analysis of the results that under tropical and subtropical conditions equation /6/ is reasonably reliable for estimating solar radiation, especially where advection, the "oasis effect", is not important in supplying additional latent heat of vaporization over a free-water surface. This equation seems to have wider application than equation $/ 4 /$, although both equations tend to approach each other. 


\section{SUMMARY}

Estimates of solar radiation $\left(R_{i}\right)$ by 15 -day periods were calculated from other available meteorological data by multiple regression analysis of $E_{o}=f\left(R_{i}, u, T_{a}, e_{d}\right)$, and then solving for $R_{i}$ from the most significant equation of the model given above. Only solar radiation wind speed $(u)$ and air temperature $\left(T_{a}\right)$ were found to correlate significantly with $E_{o}$. The solution in terms of $R_{i}$ (equation $/ 4 /$ ) then was used to obtain estimates of solar radiation for 1- to 5-day periods. The mean ratio of estimated $R_{i}$ to measured $R_{i}$ approached unity (0.95), while the coefficient of variation was 8.9 percent, as compared to 5.1 percent for the original 15 -day period data. It was found when these were compared to measured values that neglect of air temperature reduced precision of the estimates.

Equation /4/ (the indirect solution) next was evaluated on the basis of foreign data, representing extreme meteorological conditions as those in Bet Dagan, Israel and Cristobal, Panamá. This equation also was compared at the same time to a direct solution of $R_{i}$ by multiple regression analysis (equation /6/), a solution which directly minimizes the deviations about $R_{i}$. Statistical data are presented which compare the precision of the estimates by either equation $(/ 4 /$ and $/ 6 /)$.

\section{RESUMEN}

Se ha logrado obtener estimados de la intensidad de la radiación solar $\left(R_{i}\right)$ para periodos de 15 días por regresión múltiple de la relación $E_{0}=$ $f\left(R_{i}, u, T_{a}, e_{d}\right)$, resolviendo luego por radiación solar de la ecuación más significativa, siguiendo el modelo de la función anterior. Solamente demostraron correlación significativa con la evaporación del tanque $\left(E_{o}\right)$, la radiación solar, la velocidad del viento $(u)$, y la temperatura del aire $\left(T_{a}\right)$.

La solución indirecta, en términos de $R_{i}$ (ecuación /4/), fue luego evaluada comparando sus estimados para periodos de 1 a 5 días en la misma localidad (Gurabo) con los valores medidos de radiación solar. La razón media entre los valores estimados ( 1 a 5 días) y los valores medidos se acercó a uno (0.95), mientras que el coeficiente de variabilidad fue de 8.9 por ciento, comparado con 5.1 por ciento para los datos originales (periodos de 15 días). Se encontró que al eliminar la temperature del aire como parámetro en la ecuación /4/ se reduce la precisión de los estimados de radiación solar, al ser estos comparados con los valores reales.

La ecuación /4/ fue posteriormente evaluada para estimar la radiación solar de regiones donde las condiciones meteorológicas son extremas, tales como Bet Dagan, Israel y Cristobal, Panamá. Al mismo tiempo los estimados para estas regiones se compararon con los valores obtenidos por una ecuación resultante de regresión múltiple también, pero analizada para obtener $R_{i}$ directamente (ecuación /6/). Esta solución disminuye las 
desviaciones sobre regresión con respecto a $R_{i}$. Se presenta un análisis estadístico comparativo de los estimados de radiación solar por las ecuaciones $/ 4 / \mathrm{y} / 6 /$, con respecto a los valores observados y medidos.

\section{LITERATURE CITED}

1. Baier, W., and Robertson, G. W., Estimation of latent evaporation from simple weather observations, Can. J. Plant Sci. 45: 276-84, 1965.

2. Brouwer, R. Radiation intensity and transpiration, Neth.J. Agr. Sci. 4 (1): 43-8, 1956.

3. Capiel, M., The influence of supplemental irrigation and environmental factors on the yield and nutrient composition of napiergrass. Unpublished Ph.D. thesis, Utah State University, Logan, Utah, 1967.

4. Cohen, O. P., Climate and soil moisture extraction. Final Report of the Volcani Institute of Agricultural Research and the Israel Meteorological Service, Bet Dagan, Israel, 1967.

5. Kramer, P. J., and Decker, J. P., Relation between light intensity and rate of photosynthesis of loblolly pine and certain hardwoods, Plant Physiol. 19 (2): 350-8, 1944.

6. Saeki, T., Environmental Control of Plant Growth: Light relations in plant communities. Academic Press, New York, N. Y., 449 pp., 1963.

7. U. S. Weather Bureau, Climatological data, Panama Canal Zone, 1960, 1961, 1962, $1963,1965$. 